\title{
In Memory of Simeone Abramovitch Mileikovsky, 1935 to 1980
}

Beginning with the Second International Congress of Oceanography, Moscow, 1966, a number of marine scientists from virtually every western country came to know Simeone Mileikovsky, Laboratory of Plankton, Institute of Oceanology, Moscow. Inasmuch as he has never participated in meetings outside of the Soviet Union, for the vast majority of these scientists the knowledge of Simeone Mileikovsky was limited to scientific publications or correspondence.

Simeone Mileikovsky was born in Leningrad in 1935, the son of a well established Soviet economist and an associate member of the Soviet Academy of Sciences. After graduating from high school and being awarded a gold medal, he entered the faculty of Biology and Soil of the Moscow State University in 1953. In part because of the guidance of Professors L. Zenkevitch, J. Birstein, C. Abrikosov, and V. Brotskaya, he became more and more interested in marine sciences. Late in the '50's and in the early '60's he participated in summer programs in marine biology at the laboratory on the White Sea and developed close contacts with the Department of Zoology of Invertebrates which was, at that time, expanding and becoming one of the better known facilities within the Soviet Union. Through his experiences at the laboratory on the White Sea - and influenced by the work of Professor G. Thorson of Elsinor, Denmark - Simeone Mileikovsky was exposed to a field which later became his primary interest: the ecology, reproduction, and larval development of marine bottom invertebrates. Simeone Mileikovsky's first publications in 1958 were concerned with the reproduction and development of polychaetes, lunar cycles in the spawning of littoral and sublittoral invertebrates, and interactions between larvae of different benthic species.

After graduating with honors from Moscow State University, Simeone Mileikovsky occupied a position of Junior, and subsequently Senior Research Fellow, with the Laboratory of Hydrobiology and Food Sources for Fishes at the Knipovitch Arctic Institute of Fish Industry and Oceanography, Murmansk. In that capacity he participated in a number of marine expeditions to Barentsevo and the Norwegian Seas. From this experience his interests expanded to include larvae of the North Atlantic Ocean, focusing primarily on polychaetes and pteropods.

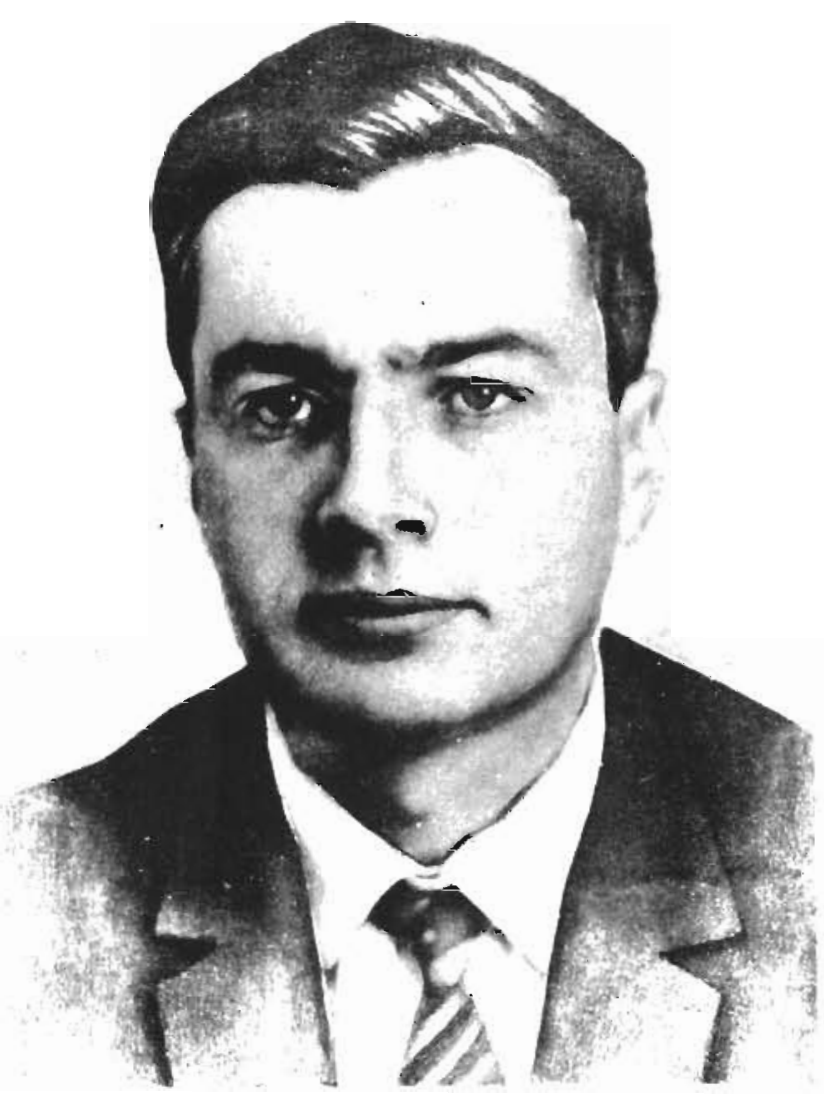

Simeone Abramovitch Mileikovsky 1935 to 1980

In 1959, S. Mileikovsky was admitted to the graduate school at the Institute of Oceanology of the Academy of Sciences, Moskow, where he worked under Professor V. Bogorov, then head of the Laboratory of Plankton. In 1962 he was accepted as a staff member within this laboratory, a position which he held until his death 18 years later. In 1965 he presented himself for promotion to $\mathrm{Ph}$. D., working on problems concerning the ecology and spawning of marine bottom invertebrates and pelagic development. This study dealt largely with material from Barentsevo, the White Sea, and the Norwegian Seas, as well as the Gulf Stream. From 1958 to $1968, \mathrm{~S}$. Mileikovsky published more than 50 papers, a number of which appeared in international journals. In the late 1960's, S. Mileikovsky became 
interested in biogeography and the scientific literature dealing with problems of marine plankton throughout the world's oceans. Several of his reviews are exceptionally well known, including "The Historical Bibliographical Review of Native Investigations on Marine Plankton over the Century 1860-1960" and "The History of Investigations on Pacific Plankton". This latter work was in part stimulated by his participation in the 39th biological cruise of the oceanographic ship "VITJAZ", headed by Professor L. Zenkevitch.

During the period 1965 to 1973 , S. Mileikovsky concentrated his efforts on a D. Sc. thesis which he presented in 1973. He had planned a monograph dealing with anthropogenic pollution in the marine environment and a second monograph concerning the ecology of polychaete larvae. Neither one of these, unfortunately, was completed at the time of his death in 1980. His final monograph, "The Ecology of Reproduction of Marine Benthos" was published in Moscow in 1981 after his death in 1980 .

Knowing of his interests and publications in the early 1960 's, I was pleased to meet S. Mileikovsky at the Second International Congress of Oceanology, Moscow, 1966. At that meeting he made an unusual effort to make contacts with western scientists and, in spite of his junior status, organized an ad hoc afternoon session dealing with "The Larvae of Marine Invertebrates". He had obviously worked hard to master Engl- ish, and it was apparent that this was the first opportunity to practice that language. A casual comment to the effect that I was interested in Russian architecture led to an all-day walking tour to churches within the city of Moscow, a tour which left his five American colleagues amazed and totally exhausted. On a number of occasions after the 1966 Congress, I had opportunities to visit Simeone in Moscow. Through these meetings we established a regular exchange of scientific literature and I became the recipient of a number of classical works by Russian authors printed prior to 1906. His Moscow apartment was jammed with international scientific literature. It was largely because of his international contacts and the resultant exchange that he developed such broad interests and turned to writing review articles which incorporated western with Soviet scientific literature.

For many of us, S. Mileikovsky represented our first contact with the Soviet scientific community. His boundless energy and enthusiasm, his voracious appetite for knowledge which knew no political bounds, and his willingness to serve as a bridge when it was not altogether popular will ensure that he will be fondly remembered by those of us who were privileged to know him.

John D. Costlow, Jr., Duke University Marine Laboratory, Beautort, USA 